\title{
Seasonal effect of vitamin D deficiency in patients with acute myocardial infarction
}

\author{
Aleksandra Tokarz ${ }^{1}$, Beata Kuśnierz-Cabała ${ }^{1}$, Marek Kuźniewski², Jacek Gacoń \\ Małgorzata Mazur-Laskowska ${ }^{4}$, Ewa Ł. Stępieñ ${ }^{5}$ \\ ${ }^{1}$ Department of Clinical Biochemistry, Jagiellonian University Medical College, Krakow, Poland \\ ${ }^{2}$ Department of Nephrology, Jagiellonian University Medical College, Krakow, Poland \\ ${ }^{3}$ Department of Invasive Cardiology, The Edward Szczeklik Hospital, Tarnow, Poland \\ ${ }^{4}$ Department of Diagnostics, University Hospital, Krakow, Poland \\ ${ }^{5}$ Department of Medical Physics, M. Smoluchowski Institute of Physics, Jagiellonian University, Krakow, Poland
}

\begin{abstract}
A b stract
Background: Vitamin D is a major regulator of mineral bone metabolism. The lower vitamin D levels in patients with acute myocardial infarction (AMI) and the seasonal variation of vitamin D levels are proposed.

Aim: The evaluation of the seasonal relationship of $25(\mathrm{OH}) \mathrm{D}$ levels in patients with $\mathrm{AMI}$ and analysis of confounding factors (gender or diabetes mellitus) affecting the levels of vitamin D in AMI patients.

Methods: Fifty-nine consecutive patients with mean age $58 \pm 9.4$ years were admitted to the Department of Invasive Cardiology. Subjects had diagnosed uncomplicated myocardial infarction. Blood samples for analysis were collected on patient admission to the cardiac unit after heparin treatment. Samples for routine laboratory tests were immediately processed. For 25(OH)D, the 25-hydroxycholecalciferol test, which measures total vitamin D levels in serum (DRG Instruments $\mathrm{GmbH}$, Marburg, Germany), was applied.

Results: Median serum 25(OH)D concentration in AMI patients was below the recommended optimal values 7.1 (2.3-13.3) $\mathrm{ng} / \mathrm{mL}$. Fifty-three (89.8\%) patients had vitamin D deficiency (VDD) below $20 \mathrm{ng} / \mathrm{mL}$, six (10.2\%) patients had suboptimal 25(OH)D levels (between $20 \mathrm{ng} / \mathrm{mL}$ and $30 \mathrm{ng} / \mathrm{mL}$ ), and no one had the recommended reference range. The seasonal effect of $25(\mathrm{OH})$ D variations among AMI patients was observed with the lowest levels in the beginning of the year (January-March) and the highest levels at the end of the year (September-December) $(p=0.007)$. Patients with normoglycaemia had significantly higher $(9.2$ [2.3-16.8] ng/mL) vitamin D levels compared to patients with impaired glucose tolerance $(2.3$ [2.3-3.9] ng/mL) or diabetes mellitus $(8.5[2.5-13.3] \mathrm{ng} / \mathrm{mL})(p=0.01)$.

Conclusions: A high prevalence of VDD in AMI patients has been confirmed. Supplementation of vitamin D in AMI patients with hyperglycaemia can bring greater benefits.
\end{abstract}

Key words: vitamin D, cardiovascular risk, myocardial infarction, clinical biochemistry

Kardiol Pol 2016; 74, 8: 786-792

\section{INTRODUCTION}

Nowadays, a large increase in interest in vitamin $\mathrm{D}$ as a potential dietary factor contributing to cardiovascular diseases has been observed [1, 2]. It has recently been reported that lower vitamin D levels may be associated with poor collateral vasculature development in patients with stable coronary artery disease [3]. The other cross-sectional analyses showed the associations between lower vitamin D levels and the risk of cardiovascular diseases or poor prognosis for patients with major adverse events (MACE) [3-6]. Moreover, the association between vitamin D deficiency (VDD) and endothelial dysfunction is well established [7]. 
In the organism, vitamin D is a major regulator of bone metabolism. However, recent data indicate their pleiotropic action in various biological processes, thus vitamin $\mathrm{D}$ is considered to be a steroid hormone involved in the intestinal absorption of calcium and the regulation of calcium homeostasis. The hormonally active form of vitamin $\mathrm{D}$ is calcitriol or $1 \alpha, 25$-dihydroxycalciferol $\mathrm{D}\left(1 \alpha, 25(\mathrm{OH})_{2} \mathrm{D}_{3}\right)$. In contrast to 25 -hydroxyvitamin $\mathrm{D}\left(25(\mathrm{OH}) \mathrm{D}_{3}\right)$, which is a prohormone and the major circulating metabolite of vitamin $\mathrm{D}$, the levels of $1 \alpha, 25(\mathrm{OH})_{2} \mathrm{D}_{3}$ are about 1000 -fold lower than those of $25(\mathrm{OH}) \mathrm{D}_{3}$. Although $1 \alpha, 25(\mathrm{OH})_{2} \mathrm{D}_{3}$ portrays the biological active form of vitamin $\mathrm{D}$, it is widely accepted that $25(\mathrm{OH}) \mathrm{D}$ is the robust indicator of vitamin D status in individuals, especially in hypovitaminosis or VDD [6].

In humans, cutaneous synthesis of vitamin $\mathrm{D}$ is responsible for $>90 \%$ of $25(\mathrm{OH}) \mathrm{D}$ levels in the serum, and some seasonal variations in circulating vitamin D levels have been observed, especially for Northern and Central European populations [8-11]. However, it is still not well recognised if there is any relationship between seasonal variation of $25(\mathrm{OH}) \mathrm{D}$ levels and the incidence of acute myocardial infarction (AMI) [4]. These associations might explain the observed relationship between the seasonal periodicity of cardiovascular mortality with a winter peak and summer nadir $[12,13]$.

The aim of the present study was to evaluate the seasonal relationship of $25(\mathrm{OH}) \mathrm{D}$ levels in patients admitted to an interventional cardiology unit because of AMI. The second aim was to investigate if there are any confounding factors (gender or diabetes mellitus [DM]) affecting the levels of vitamin D in AMI patients.

\section{METHODS}

Fifty-nine consecutive patients ( $\mathrm{n}=46$ of men) with mean age $58 \pm 9.4$ years (range 40-79) were admitted to the Department of Invasive Cardiology of the Edward Szczeklik Hospital in Tarnow (Poland) between July 2010 and March 2013. Patients had diagnosed uncomplicated myocardial infarction according to the European Society of Cardiology/American Heart Association redefined guidelines [13, 14]. According to the same criteria, patients were classified as ST elevation myocardial infarction (STEMI; $\mathrm{n}=23$ ) and non-STEMI (NSTEMI; $\mathrm{n}=36$ ). All patients underwent urgent coronary angiography and subsequent coronary intervention according to guidelines. In order to analyse the seasonal variation of 25(OH)D levels, patients were distributed into four groups according to the time of admission: (1) January-March, (2) April-June, (3) July-September, and (4) October-December.

Inclusion criteria were as follows: presence of infarct-related lesion in coronary artery identified during routine coronary angiography [15]. An additional inclusion criterion was the information about restraining of vitamin D supplementation. Estimated glomerular filtration rate was below $60 \mathrm{~mL} / \mathrm{min} / 1.73 \mathrm{~m}^{2}$. Exclusion criteria were as follows: any clinical signs of heart failure (in Killip classes II, III, and IV) observed before catheterisation, prior fibrinolysis, mechanical or electrical complications of acute coronary syndrome, left bundle branch block on electrocardiogram, anticoagulation, known malignant disease, active or chronic infection, or other inflammatory disease. All subjects gave written, informed consent in accordance with the requirements of the institutional Local Ethics Committee.

The distribution of classic risk factors (DM, arterial hypertension, and smoking status) were recorded (Table 1). Definitions of hypertension and diabetes were adopted from the scientific statements of the European Society of Cardiology (http://www.escardio.org). Impaired glucose tolerance (IGT) was defined as two-hour glucose levels rise from 7.8 to $11.0 \mathrm{mmoL}$ in the 75 -g oral glucose tolerance test. DM was classified according to the International Diabetes Federation guidelines (2012) [16].

\section{Blood sampling}

Blood samples for analysis were collected on patient admission to the cardiac unit, after heparin treatment. Samples for routine laboratory tests were immediately processed. Serum for 25(OH)D analysis was allowed to coagulate for $30 \mathrm{~min}$, centrifuged (2000 G for $10 \mathrm{~min}$ ), and frozen at $-80^{\circ} \mathrm{C}$ until further assessment.

\section{Laboratory tests}

The routine blood tests included serum glucose, creatinine, high sensitivity C-reactive protein, fibrinogen levels, and lipid profile assessment. Cardiac troponin T levels were analysed by means of high sensitivity test (Roche Diagnostics, Basel, Switzerland) during admission. The cut-off for AMI was set at the level above $14 \mathrm{ng} / \mathrm{mL}$. For 25(OH)D we used the 25-hydroxycholecalciferol test, which measures total vitamin D levels in serum (Cat. No. HYE-5334, DRG Instruments $\mathrm{GmbH}$, Marburg, Germany). The method is applied as competitive solid phase enzyme — linked immunosorbent assay (ELISA) on the HYBRID XL analyser (DRG Instruments $\mathrm{GmbH}$, Marburg, Germany). The assay is based on competition of the endogenous form of $25(\mathrm{OH}) \mathrm{D}$ with the $25(\mathrm{OH})$ D-biotin conjugate for binding to the well-coated vitamin D binding protein. After incubation, unbound conjugate is washed off and bound 25(OH)D-biotin conjugate is detected by streptavidin-peroxidase conjugate. The concentration of $25(\mathrm{OH}) \mathrm{D}$ in a patient sample is inversely proportional to the amount of detected peroxidase. The result is the effect of additive concentrations of $25(\mathrm{OH}) \mathrm{D}_{3}$ and $25(\mathrm{OH}) \mathrm{D}_{2}$. This assay detected vitamin $\mathrm{D}_{2}$ with specificity $74.7 \%$ and vita$\min D_{3}$ with specificity $100 \%$. The dynamic range of the assay is defined such as the limit of detection and maximal value on the master curve. The range of assay is between $2.3 \mathrm{ng} / \mathrm{mL}$ and $130 \mathrm{ng} / \mathrm{mL}$. The sensitivity of the method is identical to that at the beginning of the dynamic range. The total assay 
Table 1. Characteristics of the study group and a comparison with respect to gender

\begin{tabular}{|c|c|c|c|c|}
\hline & AMI group $(n=59)$ & Women $(n=13)$ & Men $(n=46)$ & $\mathbf{P}$ \\
\hline Age [years] & $58 \pm 9.4$ & $61 \pm 9.8$ & $57.0 \pm 9.3$ & 0.75 \\
\hline Body mass index $\left[\mathrm{kg} / \mathrm{m}^{2}\right]$ & $27.0(24.6-31.0)$ & $29.0(26.0-32.8)$ & $27.6(26.0-31.9)$ & 0.68 \\
\hline Current smokers & $37(62.7 \%)$ & $6(46.2 \%)$ & $31(67.4 \%)$ & 0.46 \\
\hline Diabetes mellitus & $14(23.7 \%)$ & $3(23.1 \%)$ & $11(23.9 \%)$ & 0.96 \\
\hline IGT & $11(18.6 \%)$ & $3(23.1 \%)$ & $8(17.4 \%)$ & 0.70 \\
\hline Arterial hypertension & $47(79.7 \%)$ & $10(76.9 \%)$ & $37(80.4 \%)$ & 0.93 \\
\hline $\mathrm{TC}[\mathrm{mmol} / \mathrm{L}]$ & $5.64 \pm 1.34$ & $5.92 \pm 1.87$ & $5.57 \pm 1.16$ & 0.40 \\
\hline LDL-C [mmol/L] & $3.84 \pm 1.21$ & $3.97 \pm 1.78$ & $3.80 \pm 1.00$ & 0.60 \\
\hline $\mathrm{HDL}-\mathrm{C}[\mathrm{mmol} / \mathrm{L}]$ & $1.14(0.99-1.43)$ & $1.14(1.05-1.54)$ & $1.18(0.96-1.41)$ & 0.64 \\
\hline TG [mmol/L] & $1.23(0.83-2.04)$ & $1.17(0.77-1.45)$ & $1.28(0.90-2.04)$ & 0.62 \\
\hline Glucose [mmol/L] & $6.82(5.90-8.14)$ & $5.27(4.80-6.30)$ & $6.72(5.86-8.06)$ & 0.52 \\
\hline $\mathrm{HbA} 1 \mathrm{c}[\%]$ & $6.35(5.8-7.0)$ & $6.50(5.9-7.4)$ & $5.8(5.6-6.4)$ & 0.048 \\
\hline Creatinine $[\mu \mathrm{mol} / \mathrm{L}]$ & $78.0 \pm 15.77$ & $66.9 \pm 10.27$ & $81.3 \pm 15.7$ & 0.003 \\
\hline Fibrinogen [g/L] & $3.78(3.23-4.75)$ & $4.02(3.53-4.68)$ & $3.74(3.21-4.75)$ & 0.17 \\
\hline $\mathrm{Hs}-\mathrm{CRP}[\mathrm{mg} / \mathrm{L}]$ & $4.10(1.80-11.54)$ & $6.20(1.90-18.00)$ & $3.90(1.80-7.30)$ & 0.12 \\
\hline hs-TnTmax [ng/L] & $66(30-166)$ & $82(42-104)$ & $64(26-260)$ & 0.72 \\
\hline
\end{tabular}

Values are given as mean \pm standard deviation or median (Q1-Q3); AMI — acute myocardial infarction; hs-CRP — high sensitivity C-reactive protein; HbA1c — glycated haemoglobin; HDL-C — high-density lipoprotein cholesterol; IGT — impaired glucose tolerance; LDL-C — low-density lipoprotein cholesterol; TC — total cholesterol; TG — triglycerides

Table 2. Comparing vitamin $\mathrm{D}$ concentrations - 25(OH)D $[\mathrm{ng} / \mathrm{mL}]$ - in acute myocardial infarction (AMI) patients with respect to gender and glucose tolerance

\begin{tabular}{|c|c|c|c|}
\hline AMI group $(n=59)$ & Women $(n=13)$ & Men $(n=46)$ & $\mathbf{P}$ \\
\hline $7.1(2.3-13.3)$ & $2.3(2.3-8.7)$ & $7.7(2.3-15.2)$ & $0.11^{\mathrm{a}}$ \\
\hline NG $(n=34)$ & IGT $(n=11)$ & DM $(n=14)$ & $\mathbf{P}$ \\
\hline $9.2(2.3-16.8)$ & $2.3(2.3-3.9)$ & $8.5(2.5-13.3)$ & $0.01^{\mathrm{b}}$ \\
\hline
\end{tabular}

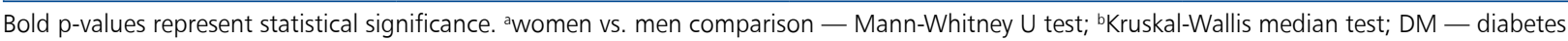
mellitus; IGT — impaired glucose tolerance; NG — normoglycaemic patients

precision is $14.6 \%$. The reference range for the Central European population was recommended on optimal (target) serum $25(\mathrm{OH}) \mathrm{D}$ concentrations ranging from $30 \mathrm{ng} / \mathrm{mL}$ to $50 \mathrm{ng} / \mathrm{mL}$ (75-125 nmol/L) [9].

\section{Statistical analysis}

It was established whether the continuous data followed the normal distribution by using the Kolmogorov-Smirnov test. Continuous variables are presented as the mean value \pm standard deviation (SD) or median with an interquartile interval (Q1-Q3). Categorical variables were expressed as absolute values or percentages and were compared by means of the $\chi^{2}$ test. Differences between mean values were verified using the Student's $t$ test when the distribution of variables was normal; in other cases the test Mann-Whitney $U$ or the Kruskal-Wallis Median test were applied. Bivariate correlations were analysed with the Pearson correlation test. P-values below 0.05 were considered significant.
Analyses were performed with Statistica Version 10 (StatSoft, Inc.) and Excel (Microsoft) software.

\section{RESULTS}

In our study we found that the median serum $25(\mathrm{OH}) \mathrm{D}$ concentration in AMI patients was 7.1 (2.3-13.3) ng/mL and this value was below the recommended reference range for healthy population (Table 2) [10]. Detailed analysis of 25(OH)D levels revealed that $53(89.8 \%)$ patients had vitamin $\mathrm{D}$ below $20 \mathrm{ng} / \mathrm{mL}$, and six (10.2\%) patients had suboptimal 25(OH)D levels (between $20 \mathrm{ng} / \mathrm{mL}$ and $30 \mathrm{ng} / \mathrm{mL}$ ). No one reached the optimal level of 25(OH)D above $30 \mathrm{ng} / \mathrm{mL}$.

Among patients with deficiency, 19 had vitamin D levels so low that the results were close to the lower limit of detection of the assay $(2.3 \mathrm{ng} / \mathrm{mL})$. Four people were classified into a group of suboptimal supply to the body with vitamin D. Interestingly, patients with normoglycaemia had significantly higher vitamin D levels than IGT or DM patients $(p=0.01$ ) 
Table 3. Comparing biochemical parameters in acute myocardial infarction (AMI) patients with respect to glucose tolerance and diabetes

\begin{tabular}{|c|c|c|c|c|}
\hline & NG $(n=34)$ & IGT $(n=11)$ & $\mathrm{DM}(n=14)$ & $\mathbf{P}$ \\
\hline $\mathrm{TC}[\mathrm{mmol} / \mathrm{L}]$ & $5.72(4.98-6.49)$ & $6.37(3.85-6.90)$ & $5.15(4.50-5.87)$ & 0.25 \\
\hline LDL-C [mmol/L] & $4.02(3.15-4.39)$ & $4.19(2.32-4.66)$ & $3.29(2.81-3.96)$ & 0.17 \\
\hline $\mathrm{HDL}-\mathrm{C}[\mathrm{mmol} / \mathrm{L}]$ & $1.20(1.09-1.45)$ & $0.99(0.94-1.25)$ & $1.16(0.95-1.45)$ & 0.17 \\
\hline TG $[\mathrm{mmol} / \mathrm{L}]$ & $1.04(0.74-1.92)$ & $1.47(1.21-2.21)$ & $1.36(0.97-2.62)$ & 0.21 \\
\hline Glucose [mmol/L] & $6.4(5.7-7.1)$ & $6.72(6.51-8.29)$ & $8.57(7.15-10.72)$ & 0.002 \\
\hline $\mathrm{HbA1c}[\%]$ & NA & $5.9(5.8-6.0)$ & $6.5(6.3-7.4)$ & $0.03^{a}$ \\
\hline Creatinine $[\mu \mathrm{mol} / \mathrm{L}]$ & $76.0(67.0-86.0)$ & $76.0(67.0-95.0)$ & $78.0(70.0-83.0)$ & 0.82 \\
\hline Fibrinogen $[\mathrm{g} / \mathrm{L}]$ & $3.83(3.26-4.75)$ & $4.02(3.23-4.45)$ & $3.50(3.15-5.48)$ & 0.91 \\
\hline $\mathrm{Hs}-\mathrm{CRP}[\mathrm{mg} / \mathrm{L}]$ & $3.80(1.60-6.30)$ & $3.90(2.20-20.60)$ & $4.85(1.60-11.54)$ & 0.56 \\
\hline
\end{tabular}

Data analysed by means of Kruskal-Wallis median test and ( $\left.{ }^{a}\right)$ Mann-Whitney $U$ test, bold p-values represent statistical significance; values are given as median (Q1-Q3); DM — diabetes mellitus; hs-CRP — high sensitivity C-reactive protein; HbA1c - glycated haemoglobin; HDL-C — high-density lipoprotein cholesterol; IGT — impaired glucose tolerance; LDL-C — low-density lipoprotein cholesterol; NA — not available; NG — normoglycaemic patients; TC — total cholesterol; TG — triglycerides

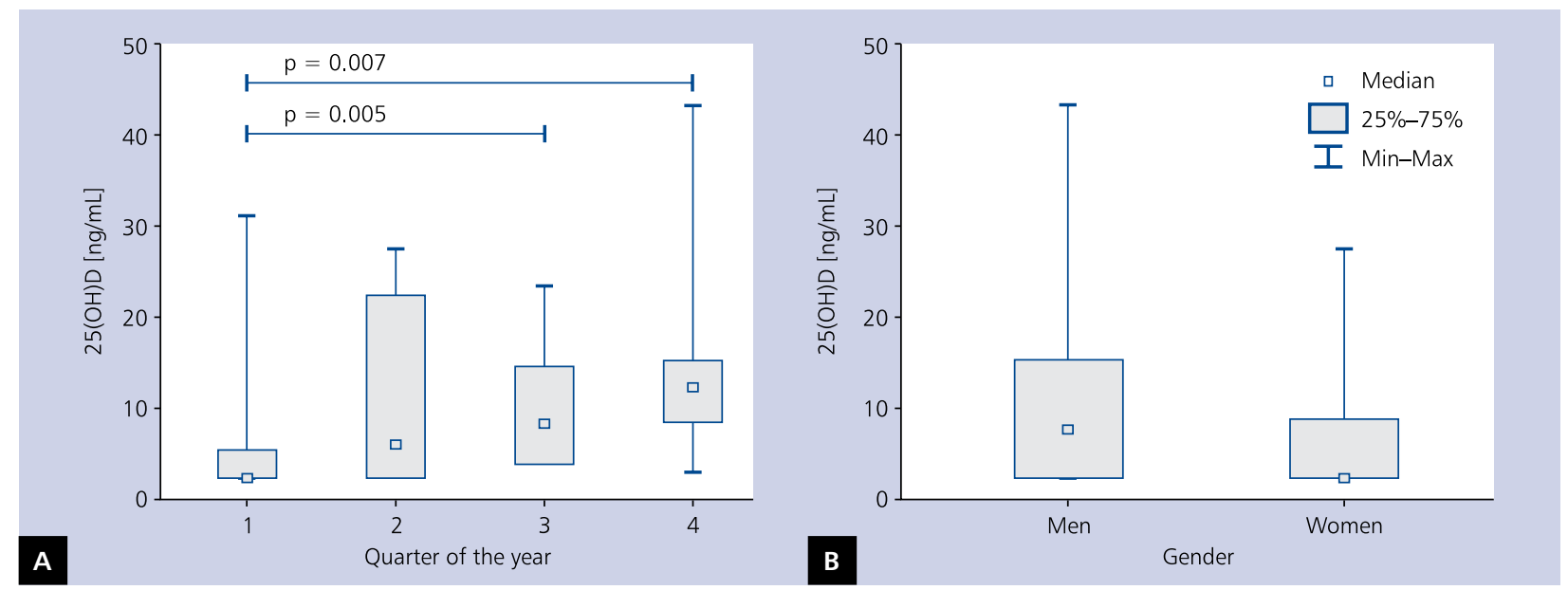

Figure 1. Graphical presentation of median values of vitamin D concentrations in acute myocardial infarction patients during admission to the Department of Invasive Cardiology; A. Seasonal changes: (1) January-March, (2) April-June, (3) July-September, and (4) October-December; B. Gender difference. Number of patients analysed in each quarter of the year: $n=18$ (1); $\mathrm{n}=10(2) ; \mathrm{n}=22(3) ; \mathrm{n}=9$ (4). Data are presented as median values with the interquartile interval and minimal-maximal values. Analysis was performed as Kruskal-Wallis median test

(Table 2). Additionally, we compared biochemical parameters in those subgroups to see if there were any relevant differences. The only significances were observed in glucose and glycated haemoglobin levels (Table 3).

The most interesting finding of our study is that patients admitted at the beginning of the year (January-March) had the lowest vitamin D levels and the highest levels at the end of the year (October-December) (2.3 [2.3-5.3] vs. 12.3 [8.3-15.2] ng/mL; $p=0.007$ ) (Fig. 1A). Consecutively, in the second quarter of the year the median $25(\mathrm{OH}) \mathrm{D}$ was $5.9(2.3-22.3) \mathrm{ng} / \mathrm{mL}$ and in the third one was 8.4 (3.9-14.5) $\mathrm{ng} / \mathrm{mL}(\mathrm{p}=0.005)$. We did not find differences in $25(\mathrm{OH}) \mathrm{D}$ between men and women, but the tendency towards lower vitamin D levels was observed in women (7.7 [2.3-15.2] vs. 2.3 [2.3-8.7] ng/mL; $\mathrm{p}=0.11$ ) (Fig. 1B). The other interesting observation was that in the first quarter of the year the concentrations of $25(\mathrm{OH}) \mathrm{D}$ negatively correlated with glucose levels $(r=-0.62 ; p=0.014)$. Such a relationship was not observed in other seasons.

A tendency towards lowering $25(\mathrm{OH}) \mathrm{D}$ levels in STEMI patients compared to NSTEMI patients was observed (2.3 [2.3-11.3] vs. 8.3 [3.2-14.9] ng/mL; $p=0.06)$. Nevertheless, the seasonal analyses with respect to DM and IGT incidence in STEMI patients were not performed due to the limited patients number.

Overall, in the DM group no correlations between biochemical and epidemiological parameters and $25(\mathrm{OH}) \mathrm{D}$ concentrations were found. However, in the IGT group we 
observed significant correlations between $25(\mathrm{OH}) \mathrm{D}$ concentrations and fibrinogen $(r=0.70 ; p=0.034)$ or triglyceride levels $(r=0.72 ; p=0.029)$. No correlations were found between sex or body mass index.

\section{DISCUSSION}

The primary finding of our study is that most AMI patients have VDD. Furthermore, we confirmed our working hypothesis that in AMI patients' vitamin D levels are subject to variations, depending on the season. This seasonal effect was so strong that it was observed even in VDD patients. Additionally, we found that hyperglycaemic conditions are related to VVD deficiency in the AMI group.

Several studies indicated that VDD is a very common finding in populations inhabiting northern latitudes [8, 9, 17]. This deficiency has been observed despite common knowledge about vitamin D sources and its potential food intake.

In our study we found that 53 patients had vitamin D levels below $20 \mathrm{ng} / \mathrm{mL}$ ( $50 \mathrm{nmol} / \mathrm{L}$ ), so we can consider that most of the AMI population suffer from VDD. Our results are taken in relation to the guidelines prepared for the population of Central Europe. According to the recommendations of prophylaxis of vitamin D deficiency in Poland, the concentration of vitamin $\mathrm{D}<20 \mathrm{ng} / \mathrm{mL}$ has been treated as VDD, and levels between $20 \mathrm{ng} / \mathrm{mL}$ and $30 \mathrm{ng} / \mathrm{mL}$ are characterised as suboptimal, with insufficient vitamin D supply to the body [10,11]. Additionally, we can confirm that the distribution of VDD in cardiovascular patients is in concordance with the previous investigation by Goleniewska et al. [4]; nevertheless, we did not check the association between the severity of coronary lesions and vitamin D levels.

However, the global recommendations are less restricted. It has been generally accepted that blood $25(\mathrm{OH}) \mathrm{D}$ levels below $10 \mathrm{ng} / \mathrm{mL}$ (or $25 \mathrm{nmol} / \mathrm{L}$ ) are qualified as 'deficient', but there is no currently accepted definition for 'optimal' $25(\mathrm{OH}) \mathrm{D}$ levels [18]. In the Central European population the correct target for supplementation is $30-50 \mathrm{ng} / \mathrm{mL}(75-125 \mathrm{nmol} / \mathrm{L})$ [11]; nevertheless, the 25(OH)D concentration should exceed $30 \mathrm{ng} / \mathrm{mL}(75 \mathrm{nmol} / \mathrm{L})$ to maximise the effect of vitamin D on calcium metabolism [18].

Despite a significant vitamin D deficiency in AMI patients we observed the seasonal effect in $25(\mathrm{OH}) \mathrm{D}$ levels, with higher levels in the fourth quarter of the year (October-December) and the lowest in the first one (winter). The seasonal variation of vitamin D serum levels is a common phenomenon in the northern hemisphere at latitudes greater than around $40^{\circ} \mathrm{N}$, where sunlight is not intense enough to generate vitamin D synthesis in the skin from October to March [18, 19]. We may consider that the seasonal deficit in sunlight during the winter months may especially affect elderly patients with high cardiovascular risk, having more deleterious effect on them [20]. However, no association between vitamin D status and incidence of ischaemic heart disease or stroke has been confirmed in the general population [21].
Vitamin D deficiency has been reported in 2-30\% of European adults, increasing in cardiovascular patients to $80 \%$ in some studies [2, 4, 22, 23]. Among factors which accompanied VDD risk, female sex is usually considered as important. In our study we observed the tendency to lower serum 25(OH)D levels in AMI women then in AMI men $(p=0.11)$. Our finding is in concordance with some recent reports showing that gender significantly affects vitamin D status in patients with coronary artery disease, and female sex is an independent predictor of cardiovascular risk [23, 24]. It is essential that in our study patients were not supplemented with vitamin D. In common practice, women in postmenopausal period are protected against osteoporosis, and vitamin D supplementation is recommended. Such substantial deficits in $25(\mathrm{OH}) \mathrm{D}$ levels may be explained by the fact that patients for this study were recruited 3-5 years ago, from a less urbanised region of Malopolska. Currently, osteoporosis prevention is more common and patients better controlled and more self-confident with respect to osteoporosis risk.

An interesting association between DM and IGT and low 25(OH)D levels was documented. Hyperglycaemia is frequently observed in patients with $\mathrm{AMI}$, in our study more than $40 \%$ of patients had DM or IGT, and hyperglycaemic conditions may favour the coagulation properties of blood in AMI [25]. However, it is still unresolved whether VDD impairs glucose tolerance or if vitamin D supplementation improves glycaemic control. We can assume that vitamin D fortification or even supplementation would be more beneficial for AMI patients with DM or IGT than for normoglycaemic ones.

\section{CONCLUSIONS}

The high prevalence of VDD in acute cardiovascular patients should be considered as an additional and interfering risk factor. In patients with previous AMI the monitoring of vitamin D levels due to its supplementation should be taken into account. Patients with hyperglycaemia may be more beneficial after vitamin D supplementation. Additional conclusion is that the vitamin D control (e.g. 25(OH)D assessment) should be provided for patients at risk to avoid over-dosage of vitamin D supplementation or insufficiency.

\section{Conflict of interest: none declared}

\section{References}

1. Zapolski T, Wysokiński A. Safety of pharmacotherapy of osteoporosis in cardiology patients. Cardiol J, 2010; 17: 335-343.

2. Pera $€$, Sygitowicz G, Białek S et al. Vitamin D and statins: action in preventing cardiovascular events. Kardiol Pol, 2012; 70: 1296-1298.

3. Sahin I, Okuyan E, Gungor B et al. Lower vitamin D level is associated with poor coronary collateral circulation. Scand Cardiovasc J, 2014; 48: 278-283. doi: 10.3109/14017431.2014.940062.

4. Goleniewska B, Kacprzak M, Zielińska M. Vitamin D level and extent of coronary stenotic lesions in patients with first acute myocardial infarction. Cardiol J, 2014; 21: 18-23. doi: 10.5603/CJ.a2013.0048. 
5. Lee JH, Gadi R, Spertus JA et al. Prevalence of vitamin D deficiency in patients with acute myocardial infarction. Am JCardiol, 2011; 107: 1636-1638. doi: 10.1016/j.amjcard.2011.01.048.

6. Ng LL, Sandhu JK, Squire IB et al. Vitamin D and prognosis in acute myocardial infarction. Int J Cardiol, 2013; 168: 2341-2346. doi: 10.1016/j.ijcard.2013.01.030.

7. Verdoia M, Schaffer A, Sartori C et al. Vitamin D deficiency is independently associated with the extent of coronary artery disease. Eur J Clin Invest, 2014; 44: 634-642. doi: 10.1111/eci.12281.

8. $\mathrm{Al}$ Mheid I, Patel R, Murrow J et al. Vitamin D status is associated with arterial stiffness and vascular dysfunction in healthy humans. J Am Coll Cardiol, 2011; 58: 186-192. doi: 10.1016/j. jacc.2011.02.051.

9. Madsen KH, Rasmussen LB, Mejborn $\mathrm{H}$ et al. Vitamin D status and its determinants in children and adults among families in late summer in Denmark. Br J Nutr, 2014; 112: 776-784. doi: 10.1017/S0007114514001263.

10. Płudowski P, Grant WB, Bhattoa HP et al. Vitamin D status in Central Europe. Int J Endocrinol, 2014; 2014: 589587. doi: 10.1155/2014/589587.

11. Płudowski P, Karczmarewicz E, Bayer M et al. Practical guidelines for the supplementation of vitamin $\mathrm{D}$ and the treatment of deficits in Central Europe: recommended vitamin D intakes in the general population and groups at risk of vitamin $\mathrm{D}$ deficiency. Endokrynol Pol, 2013; 64: 319-327.

12. Xu B, Liu H, Su N, Kong G et al. Association between winter season and risk of death from cardiovascular diseases: a study in more than half a million inpatients in Beijing, China. BMC Cardiovasc Disord, 2013; 13: 93. doi: 10.1186/1471-2261-13-93.

13. Patel NJ, Nalluri N, Deshmukh A et al. Seasonal trends of heart failure hospitalizations in the United States: a national perspective from 2000 to 2011. Int J Cardiol, 2014; 173: 562-563. doi: 10.1016/j.ijcard.2014.03.122.

14. Hamm CW, Bassand JP, Agewall S et al. Wytyczne dotyczące diagnostyki i leczenia ostrych zespołów wieńcowych bez przetrwałego uniesienia odcinka ST. Kardiol Pol, 2011; 69 (suppl. V): S203-S270.
15. Steg PG, James SK, Atar D et al. Wytyczne ESC dotyczące postępowania w ostrym zawale serca z przetrwałym uniesieniem odcinka ST. Kardiol Pol, 2012; 70 (suppl. VI): S255-S318.

16. International Diabetes Federation. The IDF Diabetes Atlas 5th Edition: A summary of the figures and key findings. Available at: http:// www.idf.org/diabetesatlas/downloads. Accessed 30 Aug 2012.

17. Krul-Poel YH, van Wijland H, Stam F et al. Study protocol: a randomised placebo-controlled clinical trial to study the effect of vitamin D supplementation on glycaemic control in type 2 diabetes mellitus SUNNY trial. BMC Endocr Disord, 2014; 14: 59. doi: 10.1186/1472-6823-14-59.

18. Huotari A, Herzig K-H. Vitamin D and living in northern latitudes: an endemic risk area for vitamin D deficiency. Int J Circumpolar Health, 2008; 67: 164-178.

19. Spiro A, Buttriss JL. Vitamin D. An overview of vitamin D status and intake in Europe. Nutr Bull, 2014; 39: 322-350.

20. Thuesen B, Husemoen L, Fenger M et al. Determinants of vitamin D status in a general population of Danish adults. Bone, 2012; 50: 605-610. doi: 10.1016/j.bone.2011.12.016.

21. Skaaby T, Husemoen LL, Pisinger C et al. Vitamin D status and changes in cardiovascular risk factors: a prospective study of a general population. Cardiology, 2012; 123: 62-70. doi: $10.1159 / 000341277$.

22. Skaaby T, Husemoen LL, Pisinger C et al. Vitamin D status and incident cardiovascular disease and all-cause mortality: a general population study. Endocrine, 2013; 43: 618-625. doi: 10.1007/s12020-012-9805-x.

23. Lips P. Vitamin D status and nutrition in Europe and Asia. J Steroid Biochem Mol Biol, 2007; 103: 620-625.

24. Schierbeck LL, Rejnmark L, Tofteng CL et al. Vitamin D deficiency in postmenopausal, healthy women predicts increased cardiovascular events: a 16-year follow-up study. Eur J Endocrinol, 2012; 167: 553-560. doi: 10.1530/EJE-12-0283.

25. Verdoia M, Schaffer A, Barbieri L et al. Impact of gender difference on vitamin D status and its relationship with the extent of coronary artery disease. Nutr Metab Cardiovasc Dis, 2015; 25 : 464-470. doi:10.1016/j.numecd.2015.01.009.

Cite this article as: Tokarz A, Kuśnierz-Cabała B, Kuźniewski M et al. Seasonal effect of vitamin D deficiency in patients with acute myocardial infarction. Kardiol Pol, 2016; 74: 786-792. doi: 10.5603/KP.a2016.0002. 


\title{
Sezonowe zmiany w niedoborach witaminy D u chorych z zawałem serca
}

\author{
Aleksandra Tokarz ${ }^{1}$, Beata Kuśnierz-Cabała ${ }^{1}$, Marek Kuźniewski ${ }^{2}$, Jacek Gacoñ ${ }^{3}$, \\ Małgorzata Mazur-Laskowska ${ }^{4}$, Ewa Ł. Stępieñ ${ }^{5}$ \\ ${ }^{1}$ Katedra i Zakład Biochemii Klinicznej, Collegium Medicum Uniwersytetu Jagiellońskiego, Kraków \\ ${ }^{2}$ Klinika Nefrologii, Collegium Medicum Uniwersytetu Jagiellońskiego, Kraków \\ ${ }^{3}$ Oddział Kardiologii Interwencyjnej, Szpital im. Edwarda Szczeklika, Tarnów \\ ${ }^{4}$ Zakład Diagnostyki, Szpital Uniwersytecki, Kraków \\ 5Zakład Fizyki Medycznej, Instytut Fizyki, Uniwersytet Jagielloński, Kraków
}

\section{Streszczenie}

Wstęp: Witamina D jest głównym regulatorem metabolizmu kostnego. W ostatnich latach obserwuje się ogromny wzrost zainteresowania witaminą D. Ze względu na jej receptorowe działanie coraz częściej jest traktowana nie tylko jako witamina, ale również jako hormon steroidowy. Klasyczna aktywność witaminy D nierozerwalnie wiąże się z gospodarką mineralną: utrzymuje homeostazę wapniowo-fosforanową i kontroluje metabolizm kostno-szkieletowy. Aktywną hormonalnie formą witaminy D jest kalcytriol lub 1 $\alpha$,25-dihydroksykalcyferol $\left(1 \alpha, 25(\mathrm{OH})_{2} \mathrm{D}_{3}\right)$. W przeciwieństwie do 25-hydroksywitaminy D $(25(\mathrm{OH}) \mathrm{D})$, która jest prohormonem i głównym krążącym metabolitem witaminy $\mathrm{D}$, stężenie $\left(1 \alpha, 25(\mathrm{OH})_{2} \mathrm{D}_{3}\right)$ jest około 1000 -krotnie niższe niż $25(\mathrm{OH}) \mathrm{D}$. Mimo że $1 \alpha, 25(\mathrm{OH})_{2} \mathrm{D}_{3}$ ukazuje biologicznie aktywną postać witaminy $\mathrm{D}$, jest powszechnie akceptowane, że to stężenie $25(\mathrm{OH}) \mathrm{D}$ jest wskaźnikiem stanu witaminy D u chorych, szczególnie u pacjentów z niedoborem witaminy D. Postuluje się, że u chorych z ostrym zawałem serca (AMI) występują niskie stężenia witaminy D, które mogą ulegać sezonowej zmienności.

Cel: Głównym celem niniejszego badania była ocena sezonowej zmiany stężenia witaminy D (25(OH)D) u pacjentów z AMI. Drugim celem było zbadanie, czy czynniki, takie jak płeć lub cukrzyca mają związek z poziomem 25(OH)D u tych chorych.

Metody: Do badania włączono 59 osób (śr. wieku $58 \pm$ 9,4 roku) przyjętych na oddział kardiologii interwencyjnej. U pacjentów stwierdzono AMI bez powikłań. Próbki krwi pobrano od chorych po podaniu heparyny, wykonując jednocześnie rutynowe oznaczenia. Pomiar stężenia 25(OH)D - witaminy D przeprowadzono z zastosowaniem metody immunoenzymatycznej (analizator HYBRID XL, DRG, Marburg, Niemcy).

Wyniki: Otrzymane wyniki interpretowano w odniesieniu do wytycznych stworzonych dla populacji Europy Środkowej. Stężenie 25(OH)D poniżej $20 \mathrm{ng} / \mathrm{ml}$ oznacza deficyt, między $20 \mathrm{ng} / \mathrm{ml}$ a $30 \mathrm{ng} / \mathrm{ml}$ charakteryzuje suboptymalne zaopatrzenie organizmu w witaminę, natomiast wartości prawidłowe, docelowe dla suplementacji wynoszą 30-50 ng/ml. Wartość mediany dla 25(OH)D mieściła się poniżej zalecanej normy: 7,1 (2,3-13,3) ng/ml. Niedobór witaminy D (< $20 \mathrm{ng} / \mathrm{ml})$ stwierdzono u $53(89,8 \%)$ chorych, u $6(10,2 \%)$ pacjentów zanotowano niskie stężenia $(20-30 \mathrm{ng} / \mathrm{ml})$, u żadnego chorego nie zaobserwowano prawidłowego stężenia witaminy D. Stwierdzono również sezonowe zmiany w stężeniach $25(\mathrm{OH}) \mathrm{D}$ : najniższe na początku roku (styczeń-marzec), a najwyższe między wrześniem a grudniem $(p=0,007)$. Chorzy z wyrównaną glikemią charakteryzowali się znacząco wyższymi stężeniami witaminy D $(9,2[2,3-16,8] \mathrm{ng} / \mathrm{ml})$ niż pacjenci z nieprawidłową tolerancją glukozy $(2,3$ [2,3-3,9] ng/ml) lub cukrzycą $(8,5[2,5-13,3] \mathrm{ng} / \mathrm{ml})(\mathrm{p}=0,01)$.

Wnioski: Potwierdzono znaczące niedobory witaminy D u chorych z AMI. Potwierdzony wysoki odsetek pacjentów z niedoborem witaminy D w grupie AMI powinien być traktowany jako dodatkowy czynnik ryzyka i czynnik zakłócający dla chorób układu sercowo-naczyniowego. U osób po przebytym AMI należy wziąć pod uwagę monitorowanie stężenia witaminy D (25(OH)D) ze względu na jej niedobór i konieczną suplementację oraz w celu uniknięcia przedawkowania witaminy D. Chorzy z hiperglikemią mogą również osiągnąć większą korzyść z suplementacji witaminy D w porównaniu z pacjentami z wyrównanym stężeniem glukozy.

Słowa kluczowe: witamina D, diagnostyka laboratoryjna, czynniki ryzyka, zawał serca

Kardiol Pol 2016; 74, 8: 786-792

Prof. Ewa Ł. Stępień, Zakład Fizyki Medycznej, Instytut Fizyki, Uniwersytet Jagielloński, ul. Łojasiewicza 1, 30-387 Kraków, e-mail: e.stepien@uj.edu.pl

Praca wpłynęła: 21.04.2015 r. Z Zaakceptowana do druku: 07.12.2015 r. Data publikacji AoP: 07.01.2016 r. 